\title{
O dendê enquanto manifestação de arte e design
}

The palm as a manifestation of art and design

PORTELA, Pablo; Doutorando em Artes Visuais; Universidade Federal da Bahia

pabloporttella@gmail.com

FACTUM, Ana Beatriz; Profa. Dra. do PPGAV - UFBA e UNEB (orientadora)

biasimon@gmail.com

\section{Resumo}

O dendê enquanto elemento da culinária nacional tem sido muito estudado e, principalmente, representado a cultura brasileira. Contudo, existem poucos trabalhos que contemplem seu aspecto poético, ou seja, seu uso em produções de artistas e designers baianos. Dessa maneira, objetiva-se investigar a expressão cultural do dendê que impacta diretamente na simbologia de trabalhos artísticos locais. Para tanto, adota-se como método a revisão de literatura para subsidiar as discussões que ampliam a relação do dendê nos contextos da arte e do design. A Fenomenologia da Percepção (MERLEAU- PONTY, 1999) foi o alicerce para compreender o dendê que está presente em processos e referências criativas de profissionais baianos, direta e indiretamente, e discutir os resultados sobre a Cultura do Pertencimento (SODRÉ, 1983).

Palavras Chave: Arte; Design; Dendê.

\section{Abstract}

The palm as an element of national cuisine has been much studied and, mainly, represented the Brazilian culture. However, there are few works that contemplate its poetic aspect, that is, its use in productions of Bahian artists and designers. In this way, the objective is to investigate the cultural expression of palm that has a direct impact on the symbology of local art works. For this, the literature review is used as a method to subsidize the discussions that extend the palm oil relationship in the contexts of art and design. The Phenomenology of Perception (MERLEAUPONTY, 1999) was the foundation for understanding the palm that is present in processes and creative references of Bahian professionals, directly and indirectly, and discussing the results on the Culture of Belonging (SODRE, 1983).

Keywords: Art; Design; Palm. 


\section{Introdução}

Este artigo apresenta resultados parciais da pesquisa de doutorado intitulada "'Mancha de dendê não sai": experimentações artísticas aplicadas ao design têxtil a partir dos componentes do dendezeiro", que está sendo desenvolvida no âmbito do Programa de Pós-Graduação em Artes Visuais, da Escola de Belas Artes, na Universidade Federal da Bahia (UFBA).

Existe uma quantidade significativa de pesquisas a respeito do dendê, principalmente como elemento agrícola, ingrediente culinário, no entanto como item explorado nas áreas de arte e design quase não há investigações que contemplem esse direcionamento. Por esse aspecto, procura-se realizar uma sistematização com vistas a produção de material bibliográfico sobre o dendê em contextos artísticos e como produção em design.

A principal motivação pela escolha do dendê se deve a sua importante presença e contribuição social em diferentes segmentos da cultura baiana, sobretudo pela possibilidade de inseri-lo ao contexto artístico e de design. Isto demonstra que são vastos os caminhos a serem trilhados e descobertos tanto para a construção de conteúdos como de criação plástica e projetual.

Esse recorte visa responder a seguinte questão: De que forma o dendê pode ser identificado culturalmente como importante elemento de pertencimento afro-brasileiro presente em produções visuais de artistas e designers baianos? Com isso, pretende-se investigar a relevância do dendê e sua relação com a arte e ao design a partir de alguns trabalhos de determinados profissionais. Dessa forma, a revisão de literatura é o suporte metodológico empregado para embasar as discussões que tem como bases teóricas a Fenomenologia da Percepção (MERLEAU-PONTY, 1999) e a Cultura do Pertencimento (SODRÉ, 1983).

Este artigo estrutura-se da seguinte forma: A “Introdução" composta por uma breve contextualização, o objeto de estudo, a proposta, a justificativa, a questão, a metodologia da pesquisa; A sessão principal "O que seria da Bahia sem o dendê?" apresenta peculiaridades do dendê enquanto manifestação presente em produções artísticas de Dorival Caymmi, Jorge Amado, Pierre Verger e Carybé; Na segunda sessão "A Fenomenologia do Dendê presente na arte e no design da Bahia" constrói-se a compreensão da utilização do dendê nos contextos artístico e do design a partir das contribuições de Merleau-Ponty (1999), e de Sodré (1983); E, por fim, as "Conclusões", onde se aborda possibilidades de experimentos e continuidade da produção artística atrelada ao universo afro-referenciado que o dendê se insere.

\section{O que seria da Bahia sem o dendê?}

O fenômeno dendê será aqui compreendido como uma poética cultural que está presente cotidianamente na vida da população baiana, sobretudo no Recôncavo Baiano e na cidade de Salvador, que abrangem diversos modos, costumes, hábitos, expressões artísticas, culinárias, artesanatos, tradições, vestuários, que utiliza diferentes fontes regionais e simbologias advindas do continente africano desde o período da colonização do Brasil.

Entende-se Poética Cultural, com base na experiência de vida de um dos autores, como formas de expressão da sensibilidade humana capazes de simbolizar, por meio da criação de imagens em diferentes superfícies, elementos culturais presentes na carga ancestral do indivíduo que são interpretados e identificados a partir do repertório de experiências adquiridos no meio social em que vive. Essa definição não se restringe quanto ao uso de ferramentas que auxiliem no 
processo de construção das imagens, mas, sobretudo, considera como relevante o ponto de partida com a escolha de referências e fontes de pesquisa que sustentarão o conhecimento poético a ser gerado no seio cultural.

A personalidade e o "jeito baiano", tão comentados pelos turistas, foram relevantes temáticas em composições musicais na segunda metade do século XX, cujas canções almejaram destacar características próprias do modo baiano de ser, viver, como exemplos: a alegria, o bomhumor, o entusiasmo, a positividade diante a resolução de problemas, a vibração, o charme, a pacificidade, a hospitalidade, o despojamento, a altivez, a pobreza e derivados, o autoritarismo e correlatos (MARIANO, 2009). Nesse aspecto, Barreto e Freitas, 2008, contribuem ao considerarem:

\begin{abstract}
Baiano é um jeito de ser, diferente, único. É uma gente mestiça, formada por brancos europeus, índios das matas tropicais e negros chegados de vários pontos da África. Um povo miscigenado, de cultura rica e religiosidade viva, sincrética. Neste lugar que é o berço do Brasil, o cantochão dos templos funde-se com o batuque dos terreiros, os pescadores cantam na puxada de rede, os negros jogam capoeira, as comidas de rua são sagradas e todos festejam em comunhão as divindades da natureza e os santos dos altares. Estado-nação cultural afro-europeu, a Bahia é um sítio latino-americano de imensa costa atlântica, com luminosidade única e um mar tão magnífico quanto azul (BARRETO E FREITAS, 2008, pp. 13-14).
\end{abstract}

Esse sentimento de pertencimento de baianidade deu-se, no percurso do século mencionado anteriormente, por meio de personalidades como Dorival Caymmi, Jorge Amado e Carybé, que foram considerados por estudiosos e pesquisadores os difusores da compreensão do que é baiano e tudo o que diz respeito a Bahia. Dorival Caymmi expressava-se através de composições musicais que criava e pelo próprio jeito de ser, vestir-se; Jorge Amado por meio da literatura com histórias relatadas sobre a vida cotidiana da população, das linguagens utilizadas, dos encantamentos naturais da cidade; Carybé, por sua vez, destacou-se no campo das artes plásticas e produções visuais com pinturas, desenhos, esculturas repletas de sentidos de baianidade (BARRETO E FREITAS, 2008). Além das características citadas acima, a liberdade e o exagero também participam da expressão baiana de ser, como explica a pesquisadora Mariano (2009, p. 182-183):

Liberdade é um ingrediente fundamental do que se considera prazeroso no discurso da baianidade e muitas são as formas de dar a vida a essa insubmissão às regras, restrições e auto-censura, sendo o exagero a medida exata, ou seja, a comprovação efetiva da desmesura e desrepressão. Exagero na alimentação - a gula -, na sensualidade, na celebração, no afeto e onde mais for oportuno.

Dentre essas duas propriedades, a liberdade de expressão a respeito da cultura baiana, do jeito baiano de ser, tornou-se com primor o principal registro identificado na produção visual das fotografias do francês Pierre Verger e nos desenhos, pinturas, murais, esculturas do argentino Carybé. Afirmam Barreto e Freitas (2008) que ambos foram encantados pela Bahia através da leitura de Jubiabá, quarta obra literária de Jorge Amado, lançada no início de 1930 e traduzida em diferentes idiomas. E Carybé, além disso, veio em busca da Bahia descrita e cantada por Caymmi.

Dessa forma, afirma Barreto (2008, p. 83), "no instante em que Verger e Carybé chegaram a esse recanto de mundo, a Bahia começava a viver um momento especial de renascimento, de crescimento, de busca de afirmação e de identidade". Significa dizer que ambos acompanharam as transformações ocorridas no percurso da Segunda Guerra Mundial, juntamente com as mudanças 
do meio social em 1960, nos âmbitos urbano, administrativo e econômico advindos do processo de ebulição cultural (BARRETO, 2008). Verger, após ter conversado em São Paulo com o sociólogo francês Roger Bastide, fortaleceu ainda mais a decisão em se mudar para Bahia e relatou a sua vivência que, de certo modo, contribuiu para desmistificar conceitos sobre a impressão que tinha do Estado:

Fui seduzido na Bahia pela presença de numerosos descendentes de africanos e por sua influência sobre a vida cotidiana deste lugar. Minha atenção era tão monopolizada por eles e pelos mulatos que durante muito tempo nem sonhava em apontar minha Rolleiflex em direção de pessoas de cores mais anêmicas (VERGER APUD RISÉRIO, 1995, p. 88).

As referências de criação utilizadas por Verger e Carybé englobavam desde o jeito de caminhar e expressar das pessoas, passando pelas manifestações e festas populares, até registros de praças, atividade de pesca, feiras livres, pontos turísticos. Os trabalhos produzidos contribuíram como geradores de mudanças, fortalecimento da identidade cultural baiana carregadas de dendê em seu sentido poético e alguns exemplos podem ser acompanhados na Figura 1.

Figura 1 - Desenho de Carybé e Fotografia de Pierre Verger sobre Baianas de Acarajé.
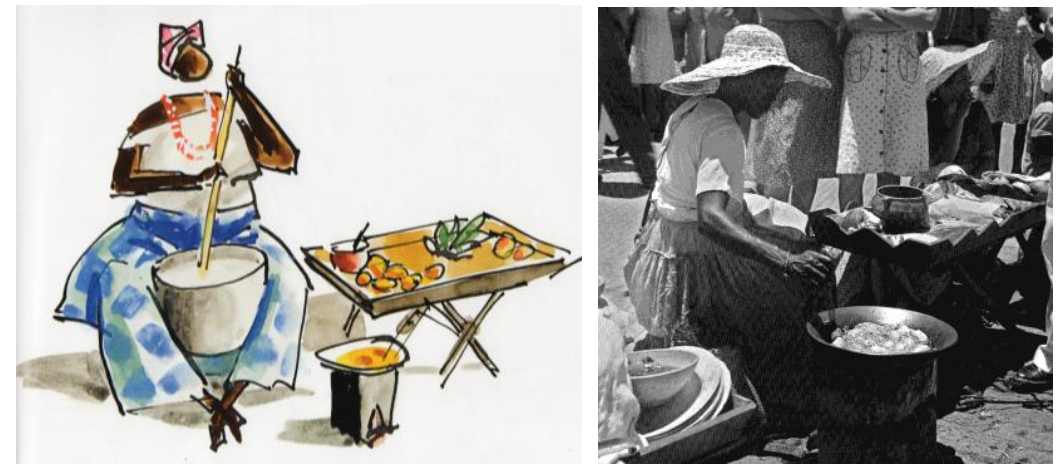

Fonte: BARRETO (2008, págs. 110, 111).

A amizade de Verger e Carybé era tão sólida como os olhares similares que tinham sobre a cultura baiana. Mesmo sem terem sido genuinamente baianos, ambos conseguiram adquirir, captar e expressar através da arte a essência cultural e poética do dendê que corriam em suas veias. Os trabalhos artísticos que produziam apresentavam um positivo entrelaçamento que construíram e reforçaram o discurso de baianidade que é apreciado, indagado, e constituem um rico acervo de imagens marcantes até os dias atuais.

E o dendê onde entra nessa história?

O dendezeiro (Figura 2), nomeado cientificamente como Elaeis guineenses Jacquin, é uma palmeira de origem africana, especificamente da Costa Oeste da África (Golfo da Guiné), que produz o fruto dendê e deste extrai-se o azeite que pode ser encontrado também como óleo de palma, desde o Senegal até Angola. Chegou ao Brasil no século XVI, pelos escravos, que deram início ao seu cultivo, principalmente nas regiões Norte, na Amazônia, e Nordeste, na Bahia, devido ao clima tropical quente e úmido encontrado no país, das propriedades do terreno fértil, que eram semelhantes ao seu habitat original na África (BOLINI, 2012; CORREA et. al., 2012; OLIVEIRA, 2009). Conforme a Revista ISTOÉ (1999, p. 55) “a palavra dendê foi trazida para a Bahia por nações 
africanas que, até o século XVIII, consistia de negros bantos de Angola e Congo. Além desta, veio também bunda, quiabo, samba, candomblé, macumba e umbanda". O dendezeiro é conhecido na língua kimbundu dos povos banto como dendém, e possui a mais importante palmácea oleaginosa de ciclo longo que pertence à família Palmaceae e ao gênero Elaeis (BOLINI, 2012, p. 15). A permanência cultural africana em território brasileiro, sobretudo no Estado da Bahia, contribuiu para o crescimento do repertório social que a mantém viva até o cotidiano do século XXI.

Figura 2 - Palmeira do dendezeiro situada na Ilha de Gameleira-BA, registro em 01/04/2018.

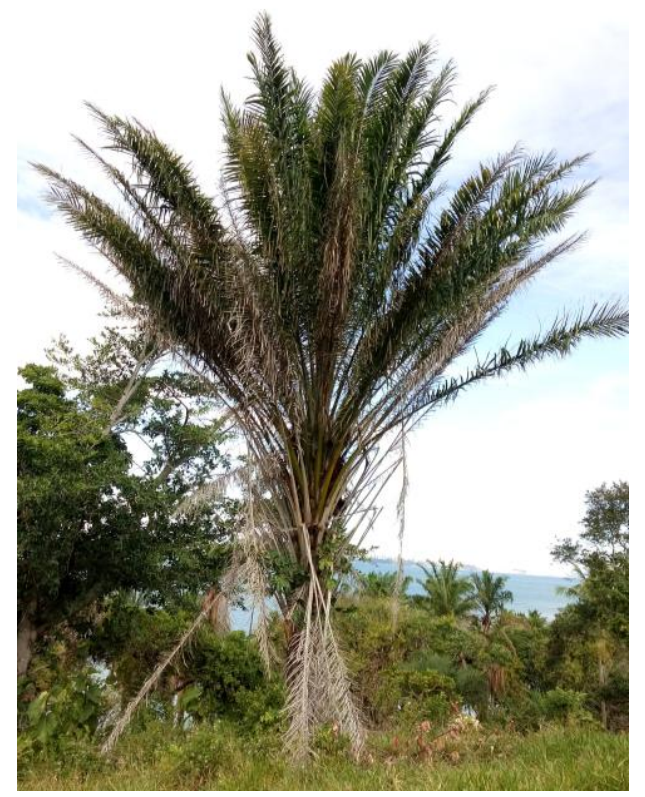

Fonte: Acervo de um dos autores (2018).

A função do dendê no século XVI era de complemento alimentar dos escravos durante a travessia no oceano até o solo nacional (LODY, 2009; LODY, 1992, OLIVEIRA, 2009). O longo caminho percorrido pelo mar até chegar em solo brasileiro foi uma das provas de resistência que o fruto passou, entre dias e noites, com temperaturas variantes. Esse percurso demonstrou a sua essência em ser um vegetal forte, tanto no sentido conotativo em aguentar e carregar peso sobre a matéria, como no denotativo de possuir energia física, vitalidade, o uso da força, advinda da raiz do continente africano. A própria constituição morfológica do dendê demonstra, interna e externamente, elementos com certo grau de dureza que precisa do auxílio de ferramentas para manuseá-lo, o que identifica uma qualidade sólida, fortalecida.

Na Bahia, especificamente, o primeiro indício de dendê ocorreu na região do Baixo Sul, em Valença, conhecida atualmente como Costa do Dendê devido a sua expansão (MORAES E PACHÊCO, 1985). O dendê cujo "fruto tem forma de côcos ovoides, de cor amarelo ou alaranjado, de tamanho variável, é composto da polpa ou mesocarpo e da semente ou caroço" (BOLINI, 2012, p. 33). Dentre as principais características do dendezeiro a que apresenta maior destaque é:

Produção de óleo por unidade de área cultivada e a capacidade do seu fruto de produzir dois óleos distintos, o da polpa, o óleo de palma, conhecido vulgarmente como azeite de dendê, de cor avermelhada, graças ao seu conteúdo de substâncias carotenoides; e o da amêndoa da semente, conhecido como óleo de palmiste. Embora distintos na aparência e 
na composição química, guardam entre si estreita afinidade: são comestíveis e importantes matérias-primas para os mais diversos segmentos industriais (OLIVEIRA, 2009, p. 28).

Neste sentido, identifica-se que os óleos extraídos do dendê não são utilizados apenas como ingrediente da culinária baiana, no caso do óleo de palma ou azeite de dendê. Na indústria alimentícia, por exemplo, serve para fabricar pães, bolos, cremes, biscoitos, margarinas, manteiga vegetal, pó para sorvetes e óleo para cozinha. Na indústria de saneantes utiliza-se na fabricação de sabão, sabão em pó, detergente, amaciante de roupas, glicerinas, velas. No segmento de cosméticos é matéria-prima para a produção de shampoos, condicionadores, sabonetes, cremes. No ramo automobilístico e de óleos usa-se para fabricar graxas, lubrificantes, combustíveis (OLIVEIRA, 2009; SOUSA JÚNIOR, 2013).

Dessa forma, encontra-se uma gama de caminhos quanto ao uso do dendê no cenário contemporâneo brasileiro, que apresenta benefícios relacionados com a saúde alimentar, estética, produtos de higiene pessoal, segmento automobilístico, dentre outros, ao ponto de extrair possibilidades de forma representativa enquanto elemento cultural marcante que suscita símbolos, cheiros, sabores, cores, texturas, tanto pela materialidade como pelas memórias do imaginário individual e coletivo. Pelo exposto, pode-se constatar a importância do dendê na vida baiana em todos os seus setores, seja na agricultura ou nas indústrias, seja na sua cultura, religião ou arte.

\section{A fenomenologia do dendê presente na arte e no design da Bahia}

As diferentes linguagens visuais produzidas por artistas e designers baianos, são recheadas com um rico acervo de conteúdos que traduzem em significados e estéticas mergulhados no dendê, tanto no aspecto poético e plástico, como no uso da sua materialidade, pois é um fenômeno, uma manifestação cultural. Independente dos materiais e das ferramentas escolhidas para a construção das obras e dos projetos, vale salientar, por exemplo, que profissionais das áreas de artes e de design nascidos no Estado da Bahia, trazem consigo o repertório criativo que Ihe são característicos pela cultura que os acompanha desde o berço e se desenvolve em seio familiar com a presença de valores, ensinamentos ancestrais, sobretudo, de identidade negra, que estão vivos no convívio social diário. Por isso entendido na base teórica da fenomenologia da percepção:

A fenomenologia é o estudo das essências, e todos os problemas, segundo ela, resumemse em definir essências: a essência da percepção, a essência da consciência, por exemplo. Mas a fenomenologia é também uma filosofia que repõe as essências na existência, e não pensa que se possa compreender o homem e o mundo de outra maneira senão a partir de sua "facticidade". É uma filosofia transcendental que coloca em suspenso, para compreendê-las, as afirmações da atitude natural, mas é também uma filosofia para a qual o mundo já está sempre "ali", antes da reflexão, como uma presença inalienável, e cujo esforço todo consiste em reencontrar este contato ingênuo com o mundo, para darIhe enfim um estatuto filosófico. É a ambição de uma filosofia que seja uma "ciência exata", mas é também um relato do espaço, do tempo, do mundo "vividos". É a tentativa de uma descrição direta de nossa experiência tal como ela é, e sem nenhuma deferência à sua gênese psicológica e às explicações causais que o cientista, o historiador ou o sociólogo dela possam fornecer, e todavia Husserl, em seus últimos trabalhos, menciona uma "fenomenologia genética" e mesmo uma "fenomenologia construtiva" (MERLEAUPONTY, 1999, pág, 1).

Identifica-se nesse conceito a relevância da palavra essência como ponto central para se 
constituir toda e qualquer base de vida humana, principalmente, no que diz respeito às experiências que o indivíduo adquire e as utiliza em prol do seu desenvolvimento. Ou seja, na filosofia fenomenológica cada pessoa encontra sua verdadeira direção, descrevendo-a, mas sem explicações e análises, potencializando como essências e mantendo-as vivas com as experiências, como determinou o filósofo Husserl, o principal criador dessa corrente (MERLEAU-PONTY, 1999).

O dendê como elemento cultural brasileiro, especialmente baiano, possui uma essência singular na formação, na conscientização e no fortalecimento da identidade negra que percorre em diferentes ambiências e funções. A cultura do pertencimento conceituada por Sodré (1983), que relaciona o dendê com o ser humano e o seu real, propõe que a assimilação de cultura com o real está atrelada com a construção feita por cada ser humano, a partir da realidade em que vive, composta por elementos tangíveis, capazes de gerar diferentes e inúmeras possibilidades. Por conta disso, a realidade é caracterizada pelas experiências, percepções individuais que se tornam únicas ao convívio em sociedade. O que torna assim o sentido do real na cultura que é aliado ao pertencimento de valores que são adquiridos em diversos contextos e captados numa apropriação particular que dialoga com o entorno, bem como na construção do repertório na forma de enxergar e interpretar o mundo (PORTELA, 2015). E, de certo modo, perpassa pelas experiências vivenciadas em cada pessoa que estabelece conexões com outras possibilidades de sentidos sem perder as características de sua essência. Dessa maneira, para exemplificar o uso do dendê como inspiração/referência para a arte e o design, tem-se os trabalhos de: Ayrson Heráclito, Ledna Barbeitos, Miro Spinelli, Goya Lopes, Ana Regina Telles dos Santos e Pablo Portela (PORTELA, 2015).

Ayrson Heráclito é artista visual, curador, professor universitário. Sua formação acadêmica constitui-se na Graduação em Licenciatura em Educação Artística na Universidade Católica do Salvador (UCSAL), concluída em 1989, no Mestrado em Artes Visuais na UFBA (1998), no Doutorado, no curso de Comunicação e Semiótica na Pontifícia Universidade Católica de São Paulo (PUC/SP), concluído em 2016. Identifica-se em alguns de seus trabalhos a simbologia de cunho alimentício que faz parte da culinária africana e baiana, como grãos, acarajé, azeite de dendê. Afirma Heráclito no Caderno Especial de Consciência Negra do Jornal A Tarde (2011), "o azeite de dendê entrou na minha obra como um dos elementos de identificação cultural", que interage a partir de performances, pinturas, esculturas (Figura 3).

Figura 3 - Trabalhos de Ayrson Heráclito.
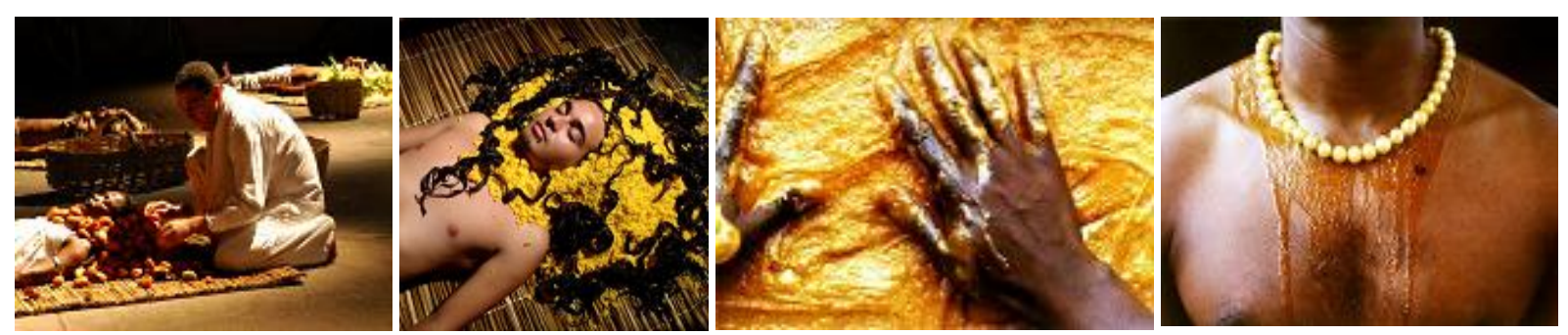

Fonte: HERÁCLITO (2014).

Pode-se constatar nessas produções artísticas que Heráclito simboliza culturalmente o pertencimento da identidade negra. As imagens que demonstram o ato de misturar o azeite de dendê nas mãos e derramá-lo sobre a pele negra, por exemplo, é uma presença da ancestralidade 
africana que revela uma estética coberta de vitalidades, memórias coletivas, diásporas, fundamentos religiosos, processos de escravização e direitos pela liberdade, fortalecimento de tradições e valores culturais advindos do continente africano que foram incorporados em território brasileiro, sobretudo baiano.

Já a artista, professora universitária Lédna Barbeitos utiliza o azeite de dendê industrial como verniz para impermeabilizar seus trabalhos, e também realiza misturas com outros materiais, como explica no Caderno Especial de Consciência Negra do Jornal A Tarde (2011) "Além disso, gosto de ter o azeite misturado com outros materiais organizados e sintéticos para poder potencializar a cor dourado, tão característica do dendê". Em sua obra "Lascaux" pode ser vista a aplicação do dendê (Figura 4).

Figura 4 - Obra "Lascaux" da artista Lédna Barbeitos.

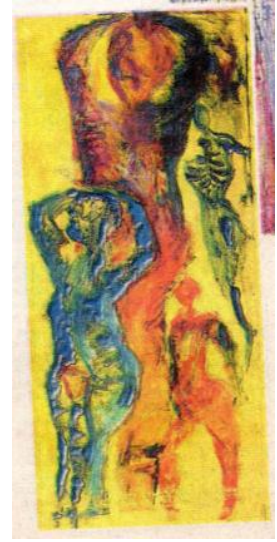

Fonte: JORNAL A TARDE (2011).

Identifica-se no trabalho de Lédna Barbeitos que o azeite de dendê usado como verniz faz refletir sobre o significado de permanência, como algo duradouro que pode servir de proteção das obras e fixação por muitos anos. A consistência da cor dourada do dendê aplicada em seus desenhos destacou e ao mesmo tempo interferiu nas cores e texturas, o que proporcionou mais luminosidade em sua obra como uma potencialidade da essência do dendê.

Tem-se o exemplo do dendê sendo usado em uma performance artística intitulada 'Gordura Trans' do artista transmídia e performer transgênero Miro Spinelli, que aconteceu no último dia do II Seminário Internacional Desfazendo Gênero, em 2015, no pátio do Campus de Ondina da UFBA (Figura 5). A ação gerou curiosidade, reflexão crítica, discriminação, sobre os padrões impostos pela sociedade e os grupos minoritários, que geralmente são alvos de deboche e preconceito (IBAHIA, 2017). 
Figura 5-Imagens da performance 'Gordura Trans'.
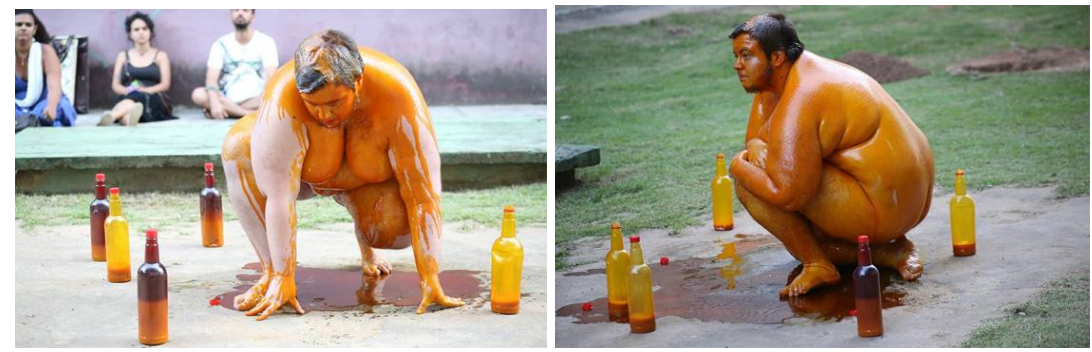

Fonte: IBAHIA (2017).

Nessa performance de Miro o azeite de dendê demarcou alguns territórios que significou um ato de resistência cultural que precisa adquirir mais respeito em convívio social: primeiro, o espaço público da universidade que interage com diferentes manifestações culturais; segundo, a falta de informação que ainda existe sobre temáticas que abordem relações de gênero; terceiro, a fartura do corpo em excesso que tanto incomoda a sociedade, as mídias e outros meios de comunicação ao comparar com a ditadura da magreza.

A artista plástica, designer Goya Lopes é empresária da marca "Goya Lopes: design brasileiro". Graduou-se em Artes Plásticas na UFBA (1976), morou na Itália entre 1977 e 1980, onde se especializou no curso de Design na Università Internazionale dell'Arte di Firenze. Em seguida, voltou à Bahia com seu propósito bem definido em tornar-se uma referência da cultura afro-brasileira no segmento de moda, decoração, e cujo trabalho com estampas está enraizado em suas pesquisas com foco na cultura afro-brasileira, unindo temas, explorando o imaginário, as possibilidades de elementos simbólicos entre a África e Bahia (LOPES, 2015), conforme a Figura 6.

Figura 6 - Produtos com estamparia afro-brasileira feitos por Goya Lopes.
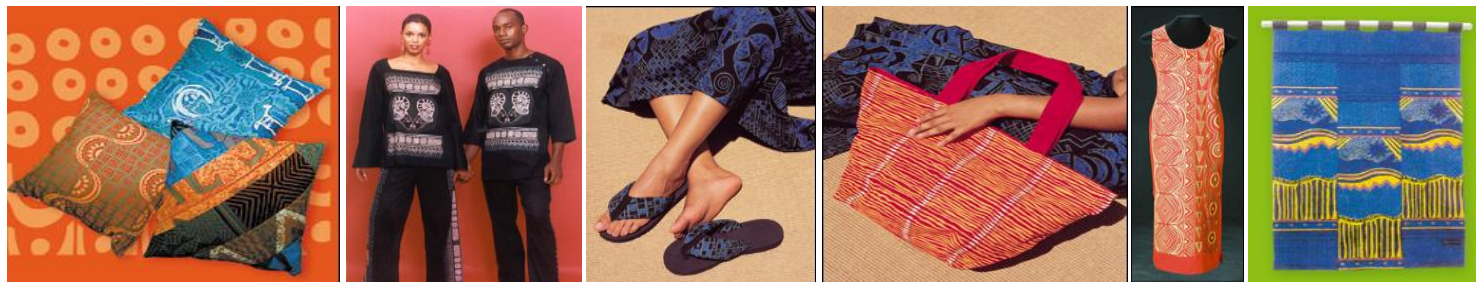

Fonte: LOPES (2015).

Os trabalhos de Lopes se caracterizam pelos traços marcantes, desenhos geométricos ancestrais, figurativos, pela cartela de cores bem iluminada e intensa entre amarelo, laranja, vermelho, bordô que simboliza fortemente as cores do dendê, pelo conteúdo dos padrões que simbolizam histórias da trajetória de negros no Brasil. Além de lendas, elementos culturais baianos, ancestrais, religiosos, afro-brasileiros, pela diversidade de produtos têxteis estampados que resgatam memórias.

A Artesã Ana Regina Telles dos Santos explora o dendê para a criação de acessórios, em que, segundo ela, a descoberta desse fruto fez suas peças simbolizarem o seu potencial cultural, ao aliar bom gosto, pesquisa e criatividade (JORNAL A TARDE, 2011). A combinação de materiais, a 
escolha dos tamanhos e das cores, a busca pelo conteúdo e sentido de existir além de ser um produto para enfeitar, agregaram valor cultural ao colar (Figura 7).

Figura 7 - Acessório com dendê da Artesã Ana Regina Telles dos Santos.

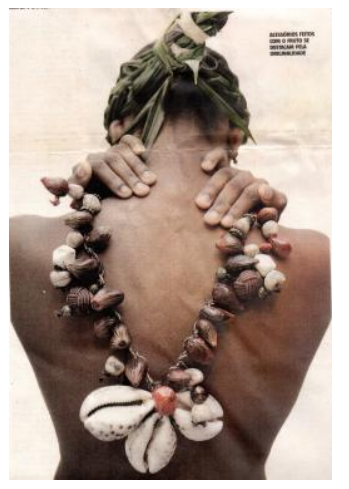

Fonte: JORNAL A TARDE (2011).

A linha de trabalho de Ana Telles caminha para a criação de acessórios tanto conceituais como comerciais que transmitem visualmente força, resistência, pertencimento cultural. Carregados de vitalidade a partir da mistura de materiais, como o dendê e o búzio, o uso desse colar da imagem acima, por exemplo, pode ser utilizado em eventos ou fundamentos religiosos, mais especificamente em terreiros de candomblé devido ao resultado estético obtido.

O último profissional apresentado é Pablo Portela, designer de moda, artista visual autodidata, professor universitário. Sua formação acadêmica é constituída da Graduação em Design e Gestão de Moda na Universidade Salvador (UNIFACS), BA, concluído em 2009; da Especialização em Design para Estamparia na Universidade Federal de Santa Maria (UFSM), RS, concluída em 2012; do Mestrado em Desenho, Cultura e Interatividade na Universidade Estadual de Feira de Santana (UEFS), BA, concluído em 2015; e do Doutorado em Artes Visuais na Universidade Federal da Bahia (UFBA), BA, em andamento. Seus trabalhos com estampas e padrões não são simples reproduções de imagens, mas sim criações que estilizam, apresentam conteúdos de diversidade temática, na composição das formas, na vivacidade das cores, na conexão com a efervescência cultural baiana presente no cotidiano, fortalecidas pela consciência de pertencimento do povo baiano, em relação à história e às suas raízes (PORTELA, 2015), de acordo com a Figura 8. 

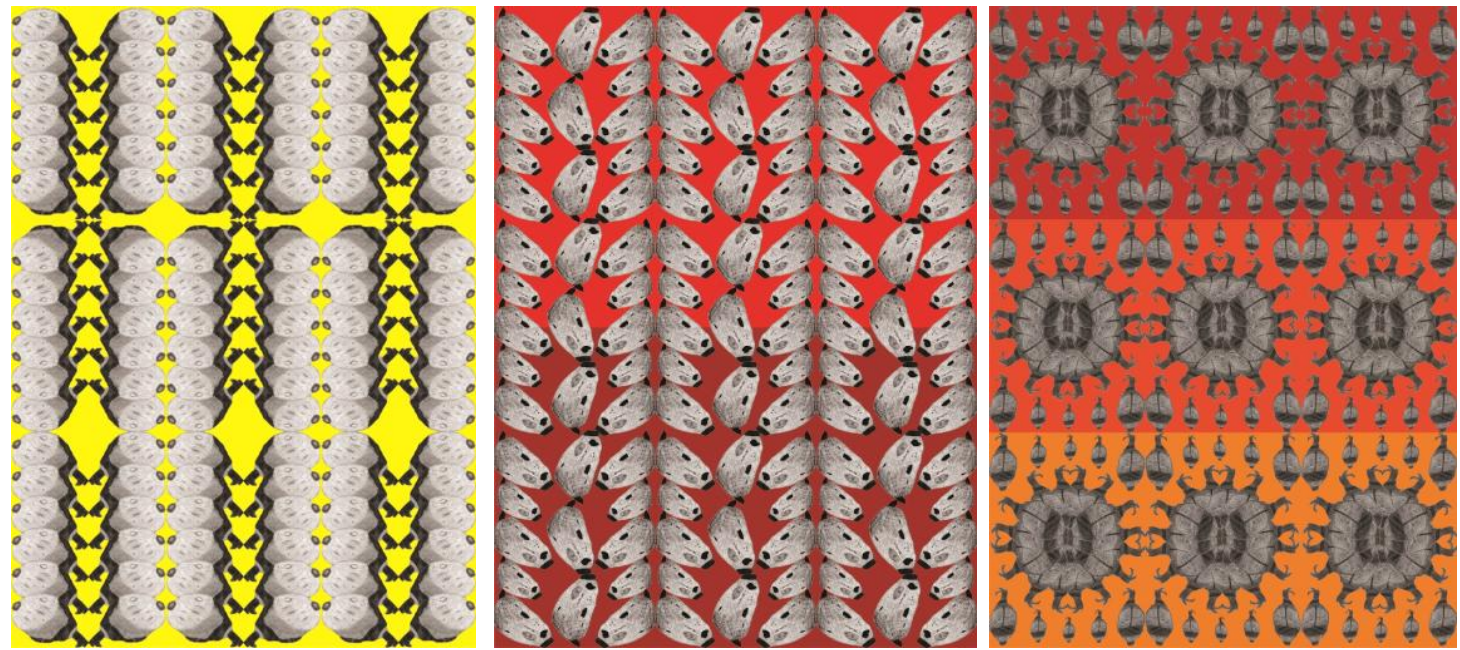

Fonte: PORTELA (2015).

Verifica-se nos exemplos acima, que em cada design têxtil criado houve uma busca de sentido e apresentou características que se aproximam da sua referência de inspiração, o dendê, tais como: as cores intensas do amarelo, dourado, laranja, vermelho, bordô; a estrutura morfológica dos desenhos do dendê feitos a mão que procurou manter as texturas; a organização espacial que, embora sejam diferentes, seguem ritmos que direcionam ao movimento dos padrões. As imagens evocadas nos projetos indicam o repertório afro-baiano contidos no seio cultural do artista que traz diferentes interpretações de acordo com o olhar de cada observador.

Diante destes exemplos, verifica-se a intensidade da essência do dendê como um fenômeno que circula em diferentes campos de atuação artística e em projetos de design, percebe-se unidade entre eles, seja pela linguagem poética, utilização de cores, formas, texturas, materiais, seja pelo conteúdo que, em sua maioria, integra-se as propostas da corrente fenomenológica e da cultura do pertencimento.

\section{Conclusão}

A filosofia da fenomenologia da percepção (Merleau-Ponty, 1999) a partir de sua base conceitual em estudar as essências e a cultura do pertencimento (Sodré, 1983) que preza pela interação da pessoa com a sua realidade, puderam abarcar o dendê como um elemento vivo que se relaciona em diferentes contextos da sociedade baiana, como na arte e no design. A identificação cultural do que é criado, desenvolvido e difundido na Bahia, transmite não somente conteúdo das linguagens visuais do que se produz, mas, também, dos significados e da estética afro-baiano em que estão imersos.

Por essa razão, os exemplos de artistas e designers baianos escolhidos possibilitou reconhecer que mesmo com a atuação de cada profissional e seus respectivos trabalhos, houveram pontos de convergência que direcionaram para uma causalidade em comum: a busca de sentido. Todos eles se cercaram de referências culturais e criaram a própria identidade sem 
mascarar ou renegar o repertório ancestral e de experiências em que estão inseridos, conforme o estilo pessoal e o segmento em que atuam.

Tais constatações apontam para a continuidade de trabalhos e experimentos acerca da produção artística com a estética e os conteúdos afro-referenciados, no intuito de fortalecer a bagagem cultural trazida e adquirida por cada profissional e explorar ainda mais a criatividade em outras superfícies, sejam abstratas ou concretas. Porém, sem perder de vista a essência poética contida no dendê que movimenta, sustenta e potencializa os diferentes segmentos de artes e em projetos de design no Estado da Bahia.

O desdobramento deste estudo na tese supracitada visa ampliar as investigações quanto as possibilidades de uso do dendê para explorá-lo de diversas formas em experimentos artísticos e em projetos de Design. Pretende-se utilizar as mais diversas expressões e linguagens, tais como performances, instalações, design têxtil, que mantenham a poética cultural como pilar em trabalhos criativos com o dendê.

\section{Referências}

BARRETO, José de Jesus. Carybé e Verger: Gente da Bahia. Salvador: Fundação Pierre Verger: Solisluna Design Editora, 2008. - (Entre Amigos).

BARRETO, José de Jesus; FREITAS, Otto. Carybé: um capeta cheio de arte. Salvador: Assembléia Legislativa do Estado da Bahia, 2008. (Coleção Gente da Bahia; v.1).

BOLINI, Eugenia Valero. Controle sanitário do azeite de dendê (Elaeis guineensis Jacquin) industrializado no estado da Bahia. 2012. 97 f. Dissertação (Mestrado em Saúde Coletiva) Universidade Federal da Bahia, Salvador, 2012.

CORREA, Denison Lima [et. al.]. Avaliação da produtividade do dendê (Elaeis guineensis) através de técnicas de sensoriamento remoto e geoprocessamento no município de Concórdia do Pará. In: SEMINÁRIO ANUAL DE INICIAÇÃO CIENTÍFICA DA UFRA, 10, 2012, Belém. Anais... Belém: 2012. p. $1-4$.

HERÁCLITO, Ayrson. Blogspot Ayrson Heráclito. Salvador: [s.n], 2006. Disponível em: <http://ayrsonheraclito.blogspot.com.br> Acesso em: 10 nov. 2014.

IBAHIA. Disponível em: <http://www.ibahia.com/detalhe/noticia/performance-ousada-comdende-fecha-seminario-internacional-da-ufba/>. Acesso em: 16 ago. 2017.

JORNAL A TARDE. Caderno Especial de Consciência Negra, 2011.

LODY, Raul. Tem dendê, tem axé: etnografia do dendezeiro. Rio de Janeiro: Pallas, 1992.

LODY, Raul (org.). Dendê: símbolo e sabor da Bahia. São Paulo: Editora Senac São Paulo, 2009.

LOPES, Goya. Didara: Design Goya Lopes. Disponível em: <http://www.goyalopes.com.br/>. Acesso em: 10 maio 2015.

MARIANO, Agnes. A invenção da baianidade. São Paulo: Annablume, 2009.

MERLEAU-PONTY, Maurice. Fenomenologia da Percepção. Tradução Carlos Alberto Ribeiro de Moura. 2. ed. São Paulo: Martins Fontes, 1999.

MORAES, J. G. L; PACHÊCO, R.G. Cultura do dendezeiro. Valença: [Departamento de Educação da CEPLAC], 1985. 
MANCHA DE DENDÊ NÃO SAI. Revista ISTOÉ, São Paulo, n. 1539, p. 52-61, mar. 1999. Edição Especial.

OLIVEIRA, Hermano Peixoto. In: LODY, Raul. Dendê: símbolo e sabor da Bahia. São Paulo: Editora Senac São Paulo, 2009.

PORTELA, Pablo Luís dos Santos Portela. Design de superfície têxtil a partir do dendê. 2015. 124f. Dissertação (Mestrado em Desenho, Cultura e Interatividade) - Universidade Estadual de Feira de Santana, Feira de Santana, 2015.

SODRÉ, Muniz. A verdade seduzida: por um conceito de cultura no Brasil. Rio de Janeiro: CODECRI, 1983.

SOUSA JÚNIOR, Vilson Caetano de. Dendezeiro: a planta de onde tudo de tira. Salvador: Brasil com Artes, 2013.

VERGER, Pierre. In: RISÉRIO, Antonio. Avant-garde na Bahia. São Paulo: Instituto Lina Bo e PM. Bardi, 1995. - (Pontos sobre o Brasil). 